\title{
PENINGKATAN KETERAMPILAN MENULIS TEKS PROSEDUR MENGGUNAKAN MODEL PEMBELAJARAN RESIPROKAL PADA MATA PELAJARAN B. INDONESIA SISWA KELAS VII SMP NEGERI 1 RAMBUTAN BANYUASIN
}

\author{
SUYATI \\ Email: Suyatifery@gmail.com \\ Guru SMP N 1 Rambutan Banyuasin
}

\begin{abstract}
Abstrak - Penelitian ini bertujuan untuk meningkatkan keterampilan menulis teks prosedur menggunakan model pembelajaran kooperatif resiprokal pada mata pelajaran Bahasa Indonesia siswa kelas VII SMP Negeri 1 Rambutan Banyuasin. Metode yang digunakan ialah metode deskriptif kuantitatif digunakan untuk mengolah karakteristik data yang berkaitan dengan jumlah rata - rata, mencari persentase, dan menyajikan data yang menarik, dan mudah dibaca. Data berupa tes digolongkan sebagai data kuantitatif dan data yang berupa observasi digolongkan sebagai data kualitatif. Berdasarkan hasil analisis data hasil belajar siswa yang diterapkannya menulis teks prosedur dengan menggunakan model pembelajaran kooperatif resiprokal, pada siklus I jumlah siswa yang mencapai ketuntasan belajar sebanyak 4 siswa dengan presentase $12,90 \%$, sedangkan pada siklus II jumlah siswa yang mencapai ketuntasan belajar sebanyak 30 siswa dengan presentase $96,77 \%$. Hasil penelitian ini diharapkan dapat meningkatkan keaktifan dan kekreatifan menuangkan ide-idenya dalam kegiatan pembelajaran menulis.
\end{abstract}

Kata Kunci-menulis, teks prosedur, resiprokal

\begin{abstract}
This study aims to improve the procedure of writing text skills using reciprocal cooperative learning models on Indonesian language subjects in class VII of SMP Negeri 1 Rambutan Banyuasin. The method used is descriptive quantitative method used to process the characteristics of data relating to the average number, search for percentages, and present data that is interesting, and easy to read. Data in the form of tests are classified as quantitative data and data in the form of observations are classified as qualitative data. Based on the results of the analysis of student learning outcomes applied to writing procedure texts using reciprocal cooperative learning models, in the first cycle the number of students who achieved learning completeness was 4 students with a percentage of $12.90 \%$, while in the second cycle the number of students who achieved mastery learning was 30 students with a percentage of $96.77 \%$. The results of this study are expected to increase the activeness and creativity of expressing their ideas in writing learning activities.
\end{abstract}

Keywords—-writing, procedure text, reciprocal 


\section{PENDAHULUAN}

Pembelajaran Bahasa Indonesia memiliki empat bentuk keterampilan yaitu keterampilan mendengarkan, berbicara, membaca dan menulis. Keempat keterampilan tersebut merupakan keterampilan yang berkaitan satu dengan lainnya. (Linda, 2016: 3)

Kegiatan berbicara dan mendengarkan (menyimak), merupakan komunikasi secara langsung, sedangkan kegiatan menulis dan membaca merupakan komunikasi secara tidak langsung. Keterampilan menulis sebagai salah satu cara dari empat keterampilan berbahasa, memiliki peranan yang sangat penting dalam kehidupan manusia. Menulis merupakan proses mengemukakan ide, pikiran, pendapat, gagasan, kedalam bentuk bahasa tuli(Karawasa, 2016: 2).

Menulis merupakan suatu keterampilan yang dipergunakan untuk menggantikan komunikasi secara langsung, tidak secara tatap muka dengan orang lain. Menulis merupakan suatu kegiatan yang produktif dan ekspresif ( Tarigan, 2013:3).

Keterampilan menulis ini tidak akan datang secara otomatis, tetapi harus melalui latihan dan pelaksanaan secara teratur. Hal ini diperkuat oleh Morsey dalam Tarigan ( 2013: 4), menulis dipergunakan, memberitahukan dan mempengaruhi dan maksud serta tujuan seperti itu hanya dapat dicapai dengan baik oleh orangorang yang dapat menyusun pikirannya dan mengutarakannya dengan jelas, kejelasan ini bergantung pada pikiran, penggunaan katakata, dan susunan kalimat.
Dalam pembelajaran bahasa Indonesia kelas VII SMP terdapat lima kegiatan menulis, yaitu menulis teks deskripsi, teks narasi, teks cerita, teks prosedur dan menulis teks laporan. Salah satu teks yang amat menjadi perhatian dalam kurikulum 2013 adalah teks prosedur. Menulis teks prosedur dapat dilakukan dengan kegiatan awal membaca petunjuk mengenai prosedur pembuatan sesuatu yang biasanya telah dipraktikkan dalam kehidupan. Saat ini membaca teks prosedur kurang diminati karena siswa cenderung mempraktekkan secara langsung tanpa membaca teks prosedur. Keterampilan menulis menuntut siswa untuk mampu menguasai pengetahuan terkait jenis tulisan yang akan dihasilkan. Dalam hal ini peneliti memfokuskan pada aspek menulis teks prosedur.

Selain itu juga diketahui bahwa dalam kegiatan menulis, khususnya menulis teks prosedur diketahui masih rendahnya antusiasme siswa dalam mengikuti pembelajaran bahasa Indonesia khususnya pembelajaran menulis teks prosedur, kurangnya pembiasaan terhadap kegiatan menulis yang menyebabkan siswa menjadi terbebani apabila mendapatkan tugas untuk menulis, sebagian siswa membutuhkan waktu yang cukup lama untuk dapat menuangkan ide dan gagasannya, siswa belum mampu dalam menuangkan ide atau gagasan dengan baik, siswa kurang bisa mengembangkan bahasa, dan keterampilan dalam menerima pembelajaran setiap siswa yang berbeda-beda. 
Selain itu, peneliti beranggapan metode pengajaran dan pembelajaran yang digunakan guru masih berupa teknik ceramah, penugasan, dan latihan dalam menyampaikan materi kepada siswa.

Penggunaan metode pembelajaran resiprokal ini dapat meningkatkan keterampilan menulis, termasuk menulis teks prosedur karena metode pembelajaran ini merupakan metode pembelajaran yang menggunakan teman sebaya yang menjadi guru, sehingga siswa bisa bertanya tanpa merasa takut kepada teman sebaya jika mereka belum memahami mengenai teks prosedur. Di samping itu, belajar dengan menggunakan metode pembelajaran dapat mengembangkan solidaritas sosial di kalangan siswa serta dapat memfasilitasi siswa dengan pengalaman untuk berinteraksi dan belajar bersama-sama dengan siswa yang memiliki latar belakang berbeda-beda.

Berdasarkan uraian-uraian di atas, peneliti memandang perlu dilakukan suatu penelitian yang berbentuk penelitian tindakan kelas untuk meningkatkan keterampilan menulis teks prosedur menggunakan model pembelajaran Kooperatif Resiprokal pada mata pelajaran Bahasa Indonesia siswa kelas VII SMP Negeri 1 Rambutan Banyuasin.

Rumusan masalah yang dikaji dalam penelitian ini adalah " Bagaimanakah meningkatkan keterampilan menulis teks prosedur menggunakan model pembelajaran kooperatif resiprokal pada mata pelajaran Bahasa Indonesia siswa kelas VII SMP Negeri 1 Rambutan Banyuasin.

\section{KAJIAN TEORITIK}

Menulis adalah menurunkan atau melukiskan lambang-lambang grafik yang menggambarkan suatu bahasa yang dipahami seseorang, sehingga orang-orang dapat membaca lambang-lambang grafik tersebut jika mereka memahami bahasa dan gambaran serta grafik yang ada (Tarigan, 2013:22).

Abidin (2013: 181) menyatakan bahwa menulis adalah sebuah proses komunikasi secara tidak langsung antara penulis dengan pembacanya.

Selanjutnya menurut Zainurrahman (2018:2), keterampilan menulis merupakan keterampilan produktif yang sifatnya untuk memproduksi bahasa demi penyampaian makna.

Berdasarkan penjelasan beberapa ahli di atas, maka dapat disimpulkan bahwa keterampilan menulis merupakan suatu proses keterampilan produktif yang dapat membaca lambang dan diimplementasikan dalam komunikasi secara tidak langsung

Teks prosedur merupakan salah satu dari jenis teks yang termasuk genre faktual subgenre prosedural. Tujuan sosial teks ini adalah mengarahkan atau mengajarkan tentang langkah-langkah yang telah ditentukan. Dengan demikian teks ini lebih menekankan aspek bagaimana melakuan sesuatu yang dapat berupasalah satunya percobaan atau pengamatan.Itu sebabnya teks ini memiliki struktur yaitu, judul, tujuan, daftar bahan(yang diperlukan untuk mencapai tujuan), urutan tahap pelaksanaan, pengamatan, dan simpulan. 
Teks prosedur (procedure) merupakan teks yang berisi langkah-langkah yang harus diikuti agar suatu pekerjaan berjalan sesuai aturannya . Di dalam teks prosedur diuraikan bagaimana sesuatu dapat dikerjakan melalui serangkaian langkah-langkah atau tindakan. Teks prosedur adalah jenis teks yang dapat dijumpai di sekitar kita (Wartiningsih, dkk: 2017:2).

Menurut Intiana (2014:179), teks prosedur adalah teks yang memberikan petunjuk tentang cara melakukan sesuatu melalui serangkaian tindakan atau langkah/menunjukan beberapa tahap sesuai dengan langkah-langkah yang telah ditentukan

Reciprocal merupakan model pembelajaran yang pertama kali dikembangkan oleh Palincsar pada tahun 1982, kemudian disempurnakan dan dioperasionalkan oleh Palincsar dan Brown pada tahun 1984.

Setidaknya terdapat empat strategi dasar yang terlibat dalam proses pembelajaran menggunakan model ini yaitu summarizing, questioning, predicting, dan clarifying.

Menurut Weinstein and Mayer dalam Tampubolon (2014:112) model mengajar resiprokal adalah merupakan model yang harus memperhatikan empat hal yaitu bagaimana siswa belajar, mengingat, berpikir, dan memotivasi diri.

Murdiyanto dan Feriyanto (2013:543) mengemukakan bahwa model mengajar resiprokal model mengajar yang lebih mengutamakan umpan balik atau feed back dan penguatan serta anak didik diberi kebebasan untuk memberi penilaian antar teman dan dibantu pemberian koreksi dari guru.

Menurut Siswanto (2012:84) model resiprokal adalah model yang menitik beratkan pergeseran peranan tanggung jawab, pemberian umpan balik dari Guru ke teman sebaya, hal demikian memungkinkan untuk meningkatkan interaksi dan aktifitas siswa. Model ini memanfaatkan teman sebagai pemberi umpan balik dari penampilannya.

\section{METODOLOGI PENELITIAN}

Subjek penelitian adalah siswa kelas VII.5 SMP Negeri 1 Rambutan Banyuasin dengan jumlah siswa 31 orang, yang terdiri dari 15 orang siswa laki-laki dan 16 siswa orang perempuan. Subjek penelitian ini dipilih dengan menggunakan metode Purposive Sampling. Purposive Sampling adalah teknik penentuan sampel dengan pertimbangan tertentu (Sugiyono, 2011:124). Pertimbangan yang diambil untuk menentukan sampel ialah nilai rata-rata kelas yang terendah mencapai KKM belajar.

Penelitian ini direncanakan pada semester genap pada bulan Desember sampai dengan Januari tahun pelajaran 2018/2019.

Penelitian ini dilaksanakan di SMP Negeri 1 Rambutan Banyuasin yang terletak di jalan Raya Palembang - SP. Padang KM. 19, Sako Kecamatan Rambutan Kabupaten Banyuasin Provinsi Sumatera Selatan.

Dalam penelitian ini peneliti menggunakan pendekatan kualitatif. Penelitian kualitatif adalah jenis penelitian yang 
menghasilkan penemuanpenemuan yang tidak dapat dicapai (diperoleh) dengan menggunakan prosedur prosedur statistik atau dengan caracara lain dari kuantifikasi (pengukuran).

Penelitian kualitatif memiliki sejumlah ciri-ciri yang membedakannya dengan jenis penelitian lainnya. Berikut ini merupakan pengkajian dan sintesis dari Bogdan \& Biklen dan Lincoln \& Guba antara lain: menggunakan latar alamiah, manusia sebagai alat (Instrumen), metode kualitatif (wawancara, pengamatan atau dokumen), bersifat deskriptif, analisis data secara induktif, teori dari dasar (grounded theory), lebih mementingkan proses dari pada hasil, adanya kriteria khusus untuk keabsahan data

Sedangkan jenis penelitian yang digunakan adalah penelitian tindakan kelanjutan penelitian eksperimen. Penelitian eksperimen merupakan penelitian yang dimaksudkan untuk mengetes dampak perlakuan. Hal ini sesuai dengan tujuan penelitian tindakan yaitu untuk mnegetahui dampak dari suatu perlakuan yaitu mencobakan sesuatu, lalu dicermati akibat dari perlakuan tersebut, merupakan kelanjutan karena sesudah diketahui dampak perlakuan, peneliti melanjutkan dengan berpikir tenang perlakuan yang lebih baik. perlakuan tersebut dicermati lagi untuk diketahui dampaknya, kemudian peneliti berpikir tentang perlakuan yang lebih baik dan sebagainya (Arikunto, 2011:97)

Penelitian ini direncanakan dengan beberapa tahapan/siklus. Penelitian tindakan kelas ini menggunakan model Kurt Lewin.
Tahapan Siklus yang dilakukan terdiri dari empat tahapan yaitu perencanaan, pelaksanaa tindakan, observasi, dan refleksi. Namun semua ini diawali dengan refleksi awal atau disebut pra penelitian.

Teknik pengumpulan data yang digunakan pada penelitian ini antara lain observasi, tes dan dokumentansi.

\section{HASIL PENELITIAN DAN PEMBAHASAN}

\section{Siklus I}

Penelitian tindakan kelas yang dilakukan melalui dua siklus ini dilakukan untuk meningkatkan keterampilan menulis teks prosedur menggunakan model pembelajaran kooperatif resiprokal pada siswa kelas VII.5 di SMP Negeri 1 Rambutan, Banyuasin. Pada kegiatan tindakan siklus I, pertemuan pertama yang dilakukan pada hari Selasa tanggal 08 Januari 2019 dan pertemuan kedua Rabu, tanggal 09 Januari 2019 yang dilaksanakan dalam dua kali pertemuan dengan masingmasing alokasi waktu $3 \times 40$ menit. Adapun peningkatan skor keaktifan siswa berdasarkan hasil observasi siklus I sebagai berikut:

Tabel 1. Rekapitulasi Nilai Observasi Siklus I

\begin{tabular}{|c|c|c|c|}
\hline \multirow[t]{2}{*}{$\mathbf{N}$} & \multirow{2}{*}{$\begin{array}{c}\text { Aspek } \\
\text { yang } \\
\text { diamati }\end{array}$} & \multicolumn{2}{|c|}{ SIKLUS I } \\
\hline & & $\begin{array}{c}\text { Pertemu } \\
\text { an I }\end{array}$ & $\begin{array}{c}\text { Pertemu } \\
\text { an II }\end{array}$ \\
\hline 1 & $\begin{array}{l}\text { Minat } \\
\text { Belajar }\end{array}$ & 26.61 & 47.58 \\
\hline 2 & $\begin{array}{l}\text { Kesungguh } \\
\text { an }\end{array}$ & 43.55 & 54.03 \\
\hline 3 & Keseriusan & 50.00 & 51.61 \\
\hline 4 & Keaktifan & 41.13 & 62.90 \\
\hline 5 & Kerjasama & 41.13 & 54.03 \\
\hline 6 & $\begin{array}{l}\text { Kehangata } \\
n\end{array}$ & 50.81 & 64.52 \\
\hline
\end{tabular}




\begin{tabular}{|c|l|c|c|}
\hline 7 & Ketertiban & 47.58 & 62.90 \\
\hline 8 & Keriuhan & 46.77 & 57.26 \\
\hline 9 & Kelancaran & 40.32 & 57.26 \\
\hline 10 & Ketepatan & 40.32 & 59.68 \\
\hline
\end{tabular}

Berdasarkan data pada tabel 4.8, rekapitulasi nilai observasi siklus I dapat diinterpretasikan bahwa :

Peningkatan terjadi pada semua aspek yang diamati. Pada pertemuan pertama, aspek minat memperoleh skor terendah dengan skor 26,61 dan aspek kehangatan memperoleh skor tertinggi yaitu 50,80. Pada pertemuan kedua, aspek minat mengalami peningkatan menjadi 47,58 dan aspek kehangatan dari skor 50,81 meningkat menjadi 64,52, dengan kategori cukup aktif pada siklus I.

Untuk selanjutnya, pengolahan data berdasarkan hasil analis yang diketahui melalui keterampilan siswa dalam menulis teks prosedur. Diketahui bahwa dari 31 siswa, pada siklus I hanya 4 siswa mencapai ketuntasan KKM yaitu 75. Dengan nilai tertinggi 82,14 dan 27 siswa belum mencapai ketuntasan KKM dengan nilai perolehan 57,14. Persentase keberhasilan pada siklus I hanya mencapai $12,09 \%$ dan mengalami peningkatan yang sangat signifikan pada siklus II menjadi 96,77\% dengan 30 siswa tuntas KKM dengan nilai tertinggi 85,71 dan 1 siswa belum mencapai KKM dengan nilai terendah 57,14 .

\section{Siklus II}

Penelitian tindakan kelas yang dilakukan melalui dua siklus ini dilakukan untuk meningkatkan keterampilan menulis teks prosedur menggunakan model pembelajaran kooperatif resiprokal pada siswa kelas VII.5 di
SMP Negeri 1 Rambutan, Banyuasin. Pada kegiatan tindakan siklus II, pertemuan pertama yang dilakukan pada hari Selasa, tanggal 15 Januari 2019 dan pertemuan kedua Rabu , 16 JAnuari 2019 yang dilaksanakan dalam dua kali pertemuan dengan masing-masing alokasi waktu $3 \times 40$ menit. Adapun peningkatan skor keaktifan siswa berdasarkan hasil observasi siklus II sebagai berikut:

TABEL 2. Rekapitulasi Nilai Observasi Siklus

II

\begin{tabular}{|c|c|c|c|}
\hline \multirow[t]{2}{*}{$\mathrm{N}$} & \multirow{2}{*}{$\begin{array}{c}\text { Aspek } \\
\text { yang } \\
\text { diamati }\end{array}$} & \multicolumn{2}{|c|}{ SIKLUS II } \\
\hline & & $\begin{array}{c}\text { Pertem } \\
\text { uan I }\end{array}$ & $\begin{array}{c}\text { Pertem } \\
\text { uan II }\end{array}$ \\
\hline 1 & $\begin{array}{l}\text { Minat } \\
\text { Belajar }\end{array}$ & 80.65 & 92.74 \\
\hline 2 & $\begin{array}{l}\text { Kesunggu } \\
\text { han }\end{array}$ & 73.39 & 91.13 \\
\hline 3 & $\begin{array}{l}\text { Keseriusa } \\
\mathrm{n}\end{array}$ & 71.77 & 95.13 \\
\hline 4 & Keaktifan & 80.06 & 91.13 \\
\hline 5 & $\begin{array}{l}\text { Kerjasam } \\
\text { a }\end{array}$ & 87.90 & 90.32 \\
\hline 6 & $\begin{array}{l}\text { Kehangat } \\
\text { an }\end{array}$ & 79.84 & 88.71 \\
\hline 7 & $\begin{array}{l}\text { Ketertiba } \\
\mathrm{n}\end{array}$ & 78.23 & 93.55 \\
\hline 8 & Keriuhan & 75.81 & 95.97 \\
\hline 9 & $\begin{array}{l}\text { Kelancara } \\
\mathrm{n}\end{array}$ & 79.84 & 91.94 \\
\hline 1 & $\begin{array}{l}\text { Ketepata } \\
n\end{array}$ & 78.23 & 97.58 \\
\hline
\end{tabular}

Peningkatan terjadi pada semua aspek yang diamati. Pada pertemuan pertama, aspek keseriusan memperoleh skor terendah dengan skor 71,77 dan aspek kerjasama memperoleh skor tertinggi yaitu 87,90 . Pada pertemuan 
kedua, aspek keseriusan mengalami peningkatan menjadi 95,13 dan aspek kerjasama dari skor 87,90 meningkat menjadi 90,32 dengan kategori aktif pada siklus II.

Untuk selanjutnya, pengolahan data berdasarkan hasil analisis yang diketahui melalui keterampilan siswa dalam menulis teks prosedur. Diketahui bahwa dari 31 siswa, pada siklus II 30 siswa mencapai ketuntasan KKM yaitu 75 . Dengan nilai tertinggi 85,71 dan 1 siswa belum mencapai ketuntasan KKM dengan nilai perolehan 57,14 . Persentase keberhasilan pada siklus II mengalami peningkatan yang sangat signifikan pada siklus II menjadi 96,77\%. Dengan demikian dapat diambil kesimpulan bahwa menulis teks prosedur dengan menggunakan model pembelajaran kooperatif resiprokal dalam pembelajaran dapat meningkatkan aktivitas siswa dan hasil belajar siswa.

\section{KESIMPULAN DAN SARAN}

Berdasarkan hasil Penelitian Tindakan Kelas (PTK) yang dilaksanakan pada kelas VII. 5 SMP Negeri 1 Rambutan Banyuasin, diperoleh kesimpulan sebagai berikut:

1. Aktivitas siswa selama proses pembelajaran melalui pembelajaran menulis teks prosedur dengan model pembelajaraan kooperatif resiprokal, pada siklus I pertemuan pertama dengan kategori kurang aktif $(38,39 \%)$, pada pertemuan kedua meningkat dengan kategori cukup aktif (52,74\%). Pada siklus II pertemuan pertama meningkat lagi dari pada siklus I pertemuan kedua dengan kategori aktif namun terjadi peningkatan persentase $(78,87 \%)$, sedangkan pada siklus II pertemuan kedua lebih meningkat lagi dari pada siklus I dan siklus ॥ pertemuan pertama dengan kategori aktif $(92,82 \%)$.

2. Aktivitas guru selama proses pembelajaran melalui pembelajaran menulis teks prosedur dengan model pembelajaraan kooperatif resiprokal, pada siklus I dengan kategori aktif (74\%), pada Pada siklus II meningkat lagi dari pada siklus I dengan kategori sangat aktif yang terjadi peningkatan persentase (86\%)

3. Hasil belajar siswa yang diterapkannya menulis teks prosedur dengan menggunakan model pembelajaran kooperatif resiprokal, pada siklus I jumlah siswa yang mencapai ketuntasan belajar sebanyak 4 siswa dengan presentase $12,90 \%$, sedangkan pada siklus II jumlah siswa yang mencapai ketuntasan belajar sebanyak 30 siswa dengan presentase $96,77 \%$.

Berdasarkan hasil penelitian yang telah disimpulkan di atas, dalam upaya meningkatkan mutu pendidikan perlu dikemukakan beberapa saran sebagai berikut:

1. Dalam pembelajaran menulis teks prosedur diharapkan kepada guru untuk lebih terampil memilih media pembelajaran sehingga siswa lebih aktif dalam belajar.

2. Dalam pembelajaran menulis teks prosedur diharapkan kepada siswa lebih 
aktif dalam belajar dan mampu untuk memahami teks prosedur.

3. Penggunaan model pembelajaran kooperatif resiprokal membawa dampak yang positif terhadap hasil belajar siswa khususnya materi menulis teks prosedur, maka diharapkan guru dapat menggunakannya.

\section{DAFTAR PUSTAKA}

Abidin, Yunus. 2013. Pembelajaran Bahasa Berbasis Pendidikan Karakter. Bandung: Refika Aditama

Intiana, Siti Rohana Hariana. 2014. Telaah Kurikulum dan Pengembangan Bahan Ajar Bahasa Indonesia. Mataram: FKIP Universitas Mataram.

Karawasa, Hasni, Sahrudin Barasandji dan Budi. 2016. " Meningkatkan Kemampuan Menulis Karangan Sederhana Siswa Kelas IV SD N Mire Melalui Penggunaan Media Gambar Seri". Jurnal Kreatif Tadulako Online Vol. 5 No 2 Hal 1-10

Linda, Roza Novi. 2016. " Pembelajaran Menulis Teks Prosedur Kompleks Siswa Kelas X SMK N 4 Bandar Lampung ". Jurnal Kata. Hal 1-11

Murdiyanto dan Feriyanto Bambang . 2013. Perbandingan Metode Demonstrasi dan Metode Resiprokal Terhadap Hasil Belajar Lompat Jauh (Studi Pada Siswa Kelas VIII SMP Negeri 1 Gapura Sumenep). Jurnal Pendidikan Olahraga dan Kesehatan, Vol (01) 3: 541-546

Siswanto, H. 2012. "Peningkatan Keterampilan Smash Permainan Bola Voli Melalui Metode Resiprokal". Jurnal Media IImu Keolahragaan Indonesia, Vol (2):82-88
Tampubolon, Saur. 2014. Penelitian Tindakan Kelas Sebagai Pengembangan Profesi Pendidikan dan Keilmuan. Jakarta: Erlangga

Tarigan, Henry Guntur. 2013. Menulis Sebagai Suatu Keterampilan Berbahasa. Bandung: Angkasa

Wartiningsih, Ana dan Patriantoro. 2017. Peningkatan Kemampuan Menulis Teks Prosedur Dengan Model Pembelajaran Pair Checks ". Jurnal Pendidikan dan Pengajaran Vol 6 No (10) Hal 1-10.

Zainurrahman. 2018. Menulis Dari Teori Hingga Praktik (Penawar Racun Plagiarisme). Bandung: Alfabeta. 